\title{
NAGLĄCE PROBLEMY Z ZAKRESU PRAKTYKI SPOWIADANIA
}

W ramach 10 dniowego Seminarium roboczego dla misjonarzy ludowych odbytego w Fuerstenried koło Monachium, O. Bernard Häring omawiał w 6 referatach nowoczesną praktykę spowiadania. Podájemy tu niektóre punkty zamieszczone w czasopiśmie Verbum, 4 (1962), fasc. I, str. 84-90, p. t. Nowoczesna praktyka spowiadania.

\section{SPOWIEDŹ W OGÓLNOŚCI}

W związku z obecną reformą Liturgii katolickiej, dokonanej na II Soborze Watykańskim, należy zaznaczyć, że pierwotną formą nauczania Kościoła jest liturgia, czyli służba Boża. Dlatego wobec faktu odnowionej liturgii nie może być mowy o zwykłym tylko sprawowaniu Sakra.* mentu Pokuty w oderwaniu od odnowionej liturgii. Sakrament Pokuty jest głoszeniem radosnej nowiny i słów o pokoju. W całym uroczystym akcie sprawowania Sakramentu Pokuty musi dochodzić do głosu fakt, że oznacza on Liturgię Wielkiejnocy. Sakrament ten ma udzielać ludziom pokoju i zmartwychwstania. Do kapłana skierowane są słowa Pana Jezusa: Pokój wam. Jak mnie posłał Ojciec $i$ ja was posyłam (J 20, 21) tzn. mocą tego samego posłannictwa i w takiej samej miłości. F'od wieloma względami spowiednicy patrzyli dotąd jednostronnie i zbyt schematycznie na zewnętrzne przekraczanie przykazań, a za mało dostrzegali momenty usprawiedliwiające penitenta. Wynikająca stąd niesprawiedliwość w ocenie penitenta musiała wywoływać rozmaite kompleksy, odrazę i spory. Bóg wydawał się demonem, a nie Ojcem. Bóg zna naszą słabość i współczuje jej. Jednakże byłoby z drugiej strony również niesłusznie, gdyby nauczanie o spowiedzi wyrodziło się tylko w ciche, usypiające opowiadanie o miłości Boga. Niebezpieczeństwo to jest tym większe, że nowoczesne kierunki np. psychoanaliza skłonne są w ogóle negować grzech. Pius XII powiedział: Największym grzechem wspótczesności jesi to, że ludzie zaczęli stopniowo coraz bardziej tracić zrozumienie dla znaczenia grzechu (1946 r.). Dawniej zbyt mocno akcentowano grzech, winę i pokutę. Dziś, gdy na nowo odkryto w liturgii elementy radości, dziękczynienia i chwały Bożej, nie rzadko zupełnie pomija się poważne, ciemne tonu mówiące o grzechu i o Wielkim Piątku.

\section{ODPOWIEDNIA DYSPOZYCJA PENITENTA}

Sakrament Pokuty jest największym darem Zmartwychwstałego Pana dla jego Kościoła. W dniu Wielkanocy, gdy przerażeni Apostołowie zgromadzili się w Wieczerniku, ukazał się im Pan Jezus mówiąc: Weźmijcie Ducha św. Którym odpuścicie grzechy sa im odpuszczone, a którym zatrzymacie, sa im zatrzymane (J 20, 23). Wszystkie akty penitenta nabierają swej wielkości, powagi i uwalniającej mocy od sakramentalnych słów pokoju.

Cokolwiek może wnieść ze swojej strony człowiek do pojednania sie z Bogiem w Sakramencie Pokuty to gotowość na działanie Boże, czyli dyspozycję. Penitent musi znajdować się na drodze do Boga. W jakiś sposób musi uzewnętrznić się jego dobra wola chociaż by na przykład w tym, że gospodarz pomodli się szczerze za znienawidzonego sąsiada. Zadanie spowiednika polega na tym, aby penitentowi dopomóc w wytworzeniu odpowiedniej dyspozycji. Chociaż nauka udzielona penitentowi, nie zaraz za pierwszym razem znajduje $u$ niego posłuch, to nie wynika z tego, by była bezowocna. Sama tylko okoliczność, że nie można penitenta w tych kilku minutach rozmowy z nim od razu przekonać o wadze jakiegoś moralnego nakazu, bynajmniej nie dowodzi, iż nie ma on praw- 
dziwej dyspozycji. Zachodzi przecież nieraz w danym wypadku, nieznajomość wprost nie do zwyciężenia. Przeciwstawienie się zewnętrzne wy maga czasu i spowiednik musi umieć czekać. Jeśli się nie uda wytworzyć w penitencie wymaganej dyspozycji nie jest mimo to dziś wskazane odsyłać go z odmową rozgrzeszenia. Raczej trzeba odłożyć absolucję i przeprowadzić jeszcze z nim rozmowę poza konfesjonałem.

\section{MATERIALNA ZUPEENOŚ́ SPOWIEDZI}

Zasadniczo suponuje się, że penitent chciał dobrze odprawiać swą spowiedź i dlatego jest ona pod względem materii zupełna. Wiele powodów zwalnia od materialnej zupełności spowiedzi. Naléży to do urzędu spowiednika, by wedle sił wspierał wysiłki penitenta, celem dobrego, zupełnego wyznania grzechów. Indagacje spowiednika mają charakter tylko pomocniczy, tam zwłaszcza, gdzie penitent wprost lub pośrednio prosi, by go pytano. Miejscem właściwym dla gruntownego pouczenia o tym, co niedozwolone jest ambona, a nie konfesjonał. Spowiednikowi o wiele bardziej powinno leżeć na sercu gotowość penitenta do poprawy, niż materialna zupełność jego spowiedzi. W konfesjonale powinien kapłan przestrzegać form przyzwoitości i uprzejmości. Trzeba zrozumieć, że 6 przykazanie nie stanowi osi wszystkiego. Odnośnie do tej dziedziny zasadą jest: raczej zrezygnować z materialnej zupełności spowiedzi, niż narazić siebie i konfesjonał na złą reputację.

\section{SAMOGWAET}

Ankiety wykazały, że $60-80^{*} \%$ młodzieży żeńskiej, a $80-90^{*} /$ młodzieży męskiej ulega tej wadzie. Nie zawsze był on tak rozpowszechniony. Przyczyn tego zjawiska należy szukać w przyśpieszonym tempie dojrzewania młodzieży, w istotnej powodzi podniet, w braku zdrowej koedukacji, a wreszcie we współczesnym pędzie ludzkości do użycia za wszelką cenę. Samogwałt jest nienaturalnym zboczeniem, dotyczącym własnego popędu płciowego, oraz zaspokojenia swej żądzy płciowej, podczas gdy naturalny kierunek popędu dąży do partnera drugiej płci. Wadzie tej należy przeciwdziałać przez wyrzeczenia w innych dziedzinach, przez dobrowolne podejmowanie i wierne spełnianie postanowień pokutnych. Umiłowanie przyrody i gotowość niesienia pomocy drugim, może działać lecząco, odwracając uwagę od własnego ja, a dążąc do tego, co realne i co może zapewnić nam prawdziwą radość. Należy zwrócić baczną uwage na podnoszące na duchu i leczące działanie Sal.ramentów św. w tym ciężkim zmaganiu z samym sobą. Nie wolno i dziś zaprzeczać, że chodzi tu o grzech ciężki. Jednakże tam gdzie zachodzi dobra wola i wątpliwość co do subiektywnie ciężkiego grzechu, nie trzeba przed Komunią św. Wymagać spowiedzi po każdym upadku.

\section{PRZEDMAEŻEŃSKIE SPOTKANIE ODMIENNYCH PECI}

Rozdział płci od siebie w dawnej rozciągłości dziś jǘ nie istnieje, ale nie znaleziono jeszcze takich form przebywania młodych razem, które by były nacechowane pełnym opanowaniem. Dochodzą już dziś do głosu w Europie przejawy form przyjętych w Stanach Zjednoczonych na tyle, że przedmałżeńskie obcowanie płciowe uważane jest za nietakt, za uchybienie wobec dobrego tonu. Zadaniem Kościoła jest ukształtowanie takiego stylu spotkań płci odmiennych, jaki odpowiadałby czasom dzisiejszym. Przy grzechach narzeczonych należy wprowadzać więcej niż dawniej rozróżnień. Przedmałżeński stosunek płciowy pozostaje wprawdzie i dla nich niedozwolony, jednak nie można wszystkich oznak czu- 
czułości i wszelkich w tym względzie uchybień uważać za grzechy subiektywnie ciężkie. Przy spowiedzi należy narzeczonym okazyjnie doradzać, aby się wypowiedzieli co do oceny grzeszności ich zachowania się, gdyż oboje skłonni są lekceważyć ją zupełnie. Co do małżeństwa należy podkreślać, że jest ono związkiem miłości i miniaturą Kościola, w której ma się dokonać zbawienie. Ale równocześnie jest ono skierowane ku dziecku. Należy więcej podkreślać, że dawanie życia fizycznego dziecku zawiera w sobie również obowiązek jego wychowania.

A to wychowanie musi odpowiadać wymogom dzisiejszej społeczności. Fałszywe byłoby przenoszenie struktur minionych stuleci do teraźniejszości. Czasy dzisiejsze wymagają takiego ojcostwa i takiego macierzyństwa, które miałoby pełne poczucie swej odpowiedzialności. Tych małżonków, których warunki zmuszają do nieprzyjmowania dalszych dzieci, nie można jednak dyspensować od obowiązku szczerego dą̇enia do wyrobienia w sobie wstrzemięźliwości. Czułości są zawsze dozwolone a nawet konieczne, gdyż małżeństwo jest rzeczywistością obejmująca dwoje ludzi.

\section{POST I SWIĘCENIE NIEDZIELI}

Abstynencja od pokarmów mięsnych w piątki była ongiś publicznym aktem czci Bożej. Sensem tego przykazania było zrezygnowanie z pokarmu ze względu na Boga. Tę rezygnację należy również dalej pielęgnować. Nie można już jednak dziś podtrzymywać poglądu, jakoby przy dzisiejszym stosowaniu zarządzeń i przy dzisiejszej praktyce dyspenz, nakaz abstynencji obowiązywał jeszcze pod grzechem ciężkim.

Czy uczestniczenie w niedzielnej mszy św. obowiązuje jeszcze pod grzechem ciężkim? Mówiąc o tym chodzi nam raczej o środek konieczny życia duchowego, o stałe pogłębianie i deklarowanie naszej łączności $z$ Arcykapłanem Jezusem Chrystusem i świętą społecznością Kościoła. $\mathrm{Na}$ terenach na których dokonał się przewrót socjalny, nie możemy już mówić o grzechu ciężkim. Najpierw kler musi zadbać o doskonałe urzą-. dzenie celebry mszy św., a dopiero wtedy może wysuwać żądania. Nawet ostatnie dekrety Pawła VI idą po tej linii. Nie oznacza to, że należy zalecać pracę w niedzielę, ale dbać o to, by niedziela była dniem uczestniczenia w Eucharystii, niż kazuistycznym przepisem. Pamiętać trzeba, że zreferowana powyżej krytyka, skierowana jest nie przeciw przykazaniom Bożym, lecz dotyczy przejściowych i związanych z czasem poglądów.

Kęty

KS. STANISEAW PIĄTEK

\section{Ks. Henryk Weryński - Kraków}

\section{- pośWIĘCENIU ROdZIN SERCu MATKI BOŻEJ}

Wydaje mi się, że - pomiędzy innymi, bardzo cennymi owocami Millenium w naszym kraju - powinno się także znaleźć wprowadzenie praktyki poświęcania rodzin Niepokalanemu Sercu N. Maryi Panny.

Uzasadnienie takiego stwierdzenia nie nastręcza moim zdaniem żaddnych trudności.

- Mam również takie głębokie przekonanie, że Ojciec św., który tyle razy klęczy, pogrążony w modlitwie przed wizerunkiem Matki Boskiej Częstochowskiej, na pewno nie będzie zdziwiony, że inicjatywa powszechnego wprowadzenia praktyki poświęcenia rodzin Sercu Matki Bożej przychodzi z Polski, Królestwa Maryi, jako przypieczętowanie obchodu Mil- 